\title{
Housing Situation of Holocaust Survivors Returning to Their Hometowns in Poland after the Second World War. EXAMPLES FROM KRAKóW AND Lódź ${ }^{1}$
}

\author{
Monika Stępień \\ (University of Warsaw) \\ e-mail: stepien.monika@gmail.com
}

Key words: Holocaust survivors, post-war Poland, returns, Kraków, Łódź [Lodz], literary personal accounts, Jewish property, housing policy, neighbours

\begin{abstract}
This article discusses the housing situation of Holocaust survivors returning to post-war Kraków and Łódź - cities which were home to two of the largest pre-war Jewish communities in Poland, and which were not destroyed during the Second World War. The author indicates and describes factors which shaped the housing situation, including wartime and post-war displacements, the plunder of Jewish property during and after the war, Polish legislation regarding its restitution, as well as the post-war housing policy of the Polish state. Personal literary accounts by Jewish people reveal not only the creation and functioning of 'camp families,' but also the peculiar, neighbourly communities full of tensions, misunderstandings and, sometimes, violence.
\end{abstract}

The topic of this article is the housing situation of Holocaust survivors returning to their hometowns in Poland. The analysis is based primarily on literary personal accounts $^{2}$ devoted to Kraków and Lódź - cities which were home to two of the largest prewar Jewish communities in Poland and were not destroyed during the Second World War.

The post-war housing situation of Polish Jews was shaped primarily by: wartime and post-war displacements, deportations, escapes, and migrations; the plunder of Jewish property (by the German occupiers, and by Polish society) during the war, and post-war Polish legislation regarding its restitution; as well as by the post-war housing policy of the Polish state which resulted in the creation of peculiar neighbourly communities full of tensions, misunderstandings and, sometimes, violence. However, before examining these communities described in the personal accounts of Jewish people, it is necessary to discuss the circumstances that led to their creation.

\footnotetext{
${ }^{1}$ The research was financed by the National Science Centre, Poland (FUGA, no. 2016/20/S/HS3/00045).

${ }^{2}$ Literary personal accounts - the entirety of autobiographical writing in its various genres. See Leociak 2005.
} 


\section{Kraków and Lódź - cities on the move}

"A room in Kraków. A room in post-war Kraków. It was such a rare occurrence, a room," writes Alona Frankel. ${ }^{3}$ This concise statement fully reflects the consequences of the war and post-war migration. ${ }^{4}$ Anna Czocher calls occupied Kraków, the seat of the General Government's administration, a city on the move. ${ }^{5}$ In the city, the policy of segregating the residents by race and then separating one from another led to, as put by Andrzej Chwalba, the creation of cities within the city: ${ }^{6}$ German, Polish, Jew$i \mathrm{sh}^{7}$ and Ukrainian. These divisions created the need to move. The migrations, however, did not only affect the population living in Kraków since the pre-war period. Refugees and displaced persons from other parts of Poland came to the city and, after the defeat of the Warsaw Uprising, there came a mass of those who had lost everything in the ruins of the capital. Deportations, expulsions and escapes became a permanent feature in the rhythm of wartime life, continually filling the train stations with new passengers and apartments with new tenants.

After the end of the war, Kraków, which suffered no major destruction, began to be flooded with new waves of people. Roma Ligocka writes, "Suddenly Kraków is full of people. That's because so many bombs fell on Warsaw that hardly any houses are left standing there. Almost none of the little Jewish towns still exist. Finding an apartment in Kraków is now very difficult." from hiding, former prisoners of concentration camps, forced labourers who had been snatched from their former homes, and those who did not want to return to their own towns and villages: "It was a time of migration. Entire groups of people changed their places of residence," writes Ligocka. ${ }^{9}$

Łódź can certainly also be called a city on the move. During the Second World War, the city was within the borders of the Reichsgau Wartheland (Warthegau), the western and northern areas of Poland that were directly incorporated into the Third Reich. An intense germanisation campaign ran throughout the occupation in Łódź, ${ }^{10}$ which had a large German population before the war. ${ }^{11}$ Poles were deported to the Third Reich or the General Government and were replaced by Germans from the Reich, the Baltic states, the Eastern Borderlands of Poland and the Białystok area, as well as from

\footnotetext{
${ }^{3}$ Frankel 2007: 84. The texts cited in the article were translated from the versions published in Polish by G. Kuhn-Deutscher.

${ }^{4}$ For more on the population displacements resulting from the Second World War, post-war border changes, repatriation agreements, and the policies of the communist regime vis-à-vis national minorities, see Eberhardt 2000; Kersten 2005; Sienkiewicz, Hryciuk (eds.) 2008.

${ }^{5}$ See Czocher 2011: 15.

${ }^{6}$ See Chwalba 2002: 5.

${ }^{7}$ After the ghetto was sealed in March 1941, Kraków Jews had to change houses several times within its limits because the Germans reduced the living space intended for them due to the deportations to the death camps. For more on this topic, see Bieberstein 1986; Zimmerer 2004; Löw, Roth 2011; Zimmerer 2017.

${ }^{8}$ Ligocka 2003: 114.

${ }^{9}$ Ligocka 2004: 339.

${ }^{10}$ In April 1940, the German authorities changed the city's name to Litzmannstadt.

${ }^{11}$ In 1937, the ethnic makeup of Łódź was the following: Poles numbered 389,500 (58.5\%), Jews 207,000 (31.1\%), Germans 53,700 (8.0\%) and other nationalities 2.4\%. See Rzepkowski 2008: 92.
} 
Romania (chiefly Bessarabia and Northern Bukovina). ${ }^{12}$ Jews were imprisoned in the second-largest (after Warsaw) ghetto in occupied Europe, which was established in February 1940. It existed until August 1944 and was the longest functioning ghetto in occupied Poland. First, the Jews of Łódź were sent there, followed by those deported from Austria, Germany, Luxembourg, the Czech lands and liquidated ghettos in the Reichsgau Wartheland, and then others from different places in central and western Europe. Most of them were murdered in the Chełmno nad Nerem (Kulmhof) or Auschwitz-Birkenau death camps.

After the defeat of the Third Reich, the majority of the Germans fled Łódź with the retreating army. Those who remained in the city were mainly women, children and the elderly, and they became targets for the anger of Polish society, which placed on them the collective responsibility for the wrongs perpetuated by the Germans. Some of those who had been entered into the German People's List (Deutsche Volksliste) during the war were deported into the interior of the USSR, while others were expelled to the British or Soviet occupation zones in Germany.

Łódź was one of the few large cities in Poland to be nearly unaffected by the destruction of war. Due to its short distance from Warsaw, the most destroyed European capital, covered with approximately 20 million cubic metres of rubble, ${ }^{13}$ it was decided that the state administration would be located in Łódź. Former residents - Polish and Jewish alike - returned to the city, but many residents of small towns in central Poland and the Eastern Borderlands also arrived. After the cities in the so-called Recovered Territories, Łódź became the largest gathering point for repatriates returning from the USSR. The character of post-war Łódź is described by authors such as Shimon Redlich:

Lodz retained its character as an industrial and proletarian city in the postwar years, but lost its multiethnic and multicultural flavor. Most of its prewar Germans disappeared. Its Jewish population was drastically diminished, and most of those Jews who settled in Lodz in the postwar years were not original Lodzer Yidn - Lodz Jews. The official postwar Communist image of the city cultivated its 'proletarianism' and its 'Polishness.' Former industrialists' mansions and villas now housed various institutions of the Communist state. Still, at least in the bleak early postwar years, Lodz was a bustling urban centre, attractive to shoppers from all over Poland. For a while it also served as an unofficial 'interim capital,' while Warsaw was being rebuilt. ${ }^{14}$

\section{"The houses were obviously not vacant and did not wait for their lawful owners" ${ }^{15}$ - post-war Jewish returns home}

Jews returning to their hometowns after the war - including Kraków and Łódź were often treated by their Polish neighbours as spectres of the past, and their presence caused surprise and even aroused anxiety. "Supposedly they were murdered, and again

\footnotetext{
12 Radziszewska 2010: 209.

${ }^{13}$ See Szymańska (comp.) 2015; Grzebałkowska 2015.

${ }^{14}$ Redlich 2010: 33.

${ }^{15}$ Lasman 1997: 16.
} 
they are so many," grumbled a woman at the train station in Kraków at the sight of a group of prisoners returning from the camps. ${ }^{16}$ The returning Jews were viewed suspiciously and questioned about their wartime experiences - that they managed to survive was marvelled at. They were subjected to whispers behind their backs and often also openly attacked. Yoram Gross recalls the reception his mother met in Kraków: "My mother had many friends in Krakow who greeted her warmly and were delighted to see her again. There were also others, less friendly, who seemed surprised, who would say: 'Oh! Mrs Gross, so you're still alive?' as if they were somehow disappointed at finding her among the living." ${ }^{17}$ To returning survivors, their hometowns seemed to be inhospitable places, populated by crowds of indifferent or hostile people living in a cemeterycity, a city of the shadows of murdered loved ones.

The interactions between the returnees and those who had taken over their former flats and homes during or just after the war were particularly negative. "Our apartment on the top floor was occupied by strangers who would not even let me in over the threshold to look at my own room," 18 writes Halina Nelken of her return to Kraków. She spent the first few nights in her hometown staying with various neighbours. Not all of the returnees could count on such kindness. Luna Kaufman recalls a visit to her family's tenement house, which was built by her grandfather. The pre-war janitor, still working there, greeted her with a bitter remark indicating her dissatisfaction with the survival and return of the rightful heir to the building. The old, non-Jewish tenants still occupied their flats. Only Kaufman's family flat had changed hands. Now it was they, alien and without roots in this place, who called her flat home. ${ }^{19}$

It happened that Jewish homes were occupied not by total strangers, but close neighbours - some of them at the request of the owners themselves so they would be protected from confiscation by the German authorities and recovered after the war. Hope for this often turned out to be false, as it was for Józef Bau: "Nothing had changed. The house remained the same house, but my former neighbours who met me on the stairs told me that our flat was occupied by the caretaker who had received the keys from my father when we left our family nest on the orders of the German invaders and moved to the ghetto. They revealed to me, quietly and in secret, that next to the door was a chair, and on that chair lay a knife. I did not ask about anything more." 20

The experiences of Polish Jews returning home after the war and their relations with their Polish neighbours has been analysed by, among others, Jan Tomasz Gross. ${ }^{21}$ In his reflections on the causes of post-war violence against Jews by Polish society, he treated antisemitism as the main explanation, not dedicating much space to the Poles' psychological and material conditions. These were carefully examined by Marcin Zaremba, who writes that post-war aggression of Poles towards Jews resulted from many factors. Zaremba claims that for Poles impoverished by the war, the return of the old owners of their homes was a threat to their economic existence. The answer

\footnotetext{
${ }^{16}$ Bronner 1991: 164.

${ }^{17}$ Gross 2011: 165.

${ }^{18}$ Nelken 1999: 267.

${ }^{19}$ See Kaufman 2009: 128.

${ }^{20}$ Bau 1995: 40.

${ }^{21}$ Gross 2008.
} 
to the question of hostility towards returning Jews could thus be found not only on the basis of antisemitism, but also on the basis of sociobiology and the animal struggle for a nest, which was fuelled by the institutional vacuum in the immediate post-war period and the sense of chaos. Zaremba stresses, however, that the fear of losing one's flat due to the return of its former owners brought about inter-ethnic distance and, in effect, intensified antisemitism. ${ }^{22}$

\section{"Abandoned property" - restitution of Jewish property}

Some of the returnees took their fight for their flats and homes to the courts. The issue of the restitution of property, both movable and immovable, was regulated by an 8 March 1946 decree on abandoned and formerly German property (Dekret o majątkach opuszczonych i poniemieckich). ${ }^{23}$ The property of Polish Jews was classified as "abandoned." Pursuant to the decree, this category was to include assets over which the rightful owners lost control as a result of the war starting 1 September 1939, as well as those that were transferred by the owners to a third party in order to avoid confiscation. Immediately after the end of the occupation, "abandoned" property remained in the hands of private persons or the local administration units. Control over them was soon taken over by the liquidation offices (urzędy likwidacyjne). According to the law, people who had come into possession of "abandoned" property were obligated to report it to the authorities. In practise, however, many people did not report their possession of "abandoned" property.

The pre-war owners (or their next of kin) could apply to the courts of first instance (sady grodzkie - district courts;) to reclaim ownership (przywrócenie posiadania). If successful, the claimant would reclaim ownership of the physical property without a title (tytut własności). ${ }^{24}$

Due to the frequent lack of documents allowing for the unambiguous determination of who had owned property before the war, what had happened to those people and their property during the war, and the identity of their closest relatives, a decisive role was played by witnesses, which created a field for various abuses. Henryk Vogler, a lawyer by education, appearing before the Kraków courts during the post-war period, writes: "Sometimes it happened that the alleged deceased - killed off by the self-proclaimed relatives, planted witnesses, advocates and judges - returned unexpectedly from abroad. But it was too late. Perjury, fraud or ordinary theft were in the meantime sanctioned by legal regulations and the new owners could sleep peacefully." 25

Some survivors gave up the fight for their property or tried to recover it amicably, without the participation of the courts - this particularly concerned the monetary equivalent of the taken-over real estate, as well as the movable property given to neighbours, employees, acquaintances or strangers for safekeeping. Rut Kornblum-Rosenberger recalls:

\footnotetext{
${ }^{22}$ See Zaremba 2012: 483.

${ }^{23}$ For more on the looting and restitution of Jewish property, see Krawczyk 2011: 687-713; Grabowski, Libionka (eds.) 2014; Krzyżanowski 2016.

${ }^{24}$ See Cichopek-Gajraj 2014: 72-74.

${ }^{25}$ Vogler 1981: 22-23.
} 
[...] We went into our former store. We were greeted by the Polish Volksdeutsch who was selling fancy goods in the shop. He turned to Michat [the father of her friend] and asked if he could help. 'Indeed you can,' replied Michał. 'This is the daughter of the shop owner. Either you, sir, will pay her handsomely or she'll go to the court.' The owner went pale and offered me a ridiculously small amount. Michał looked at him with contempt and said: 'Unnecessary. Come, Rina, to the court with us.' The owner immediately surrendered and offered me a sum several times higher. I accepted it. [...] The most important thing was to have some resources to survive until my father returns. ${ }^{26}$

The authors of literary personal accounts note the different attitudes of those to whom property, often valuable, was left for safekeeping. For example, Ester Friedman describes the friendly attitude of a neighbour lady who managed to save the objects entrusted to her during the war. Most of them were returned to their rightful owners, who could also count on additional help from the woman. This help, provided without the knowledge of her husband, certainly required empathy, but also courage. It was thus of greater value for those who experienced it:

I asked my Mama and we went to our former neighbour, Mrs Pekajowa. She was very pleased. She was doing well and had a shop. I could always bathe at her place, but only when her husband was not at home. He couldn't look at Jews. Mrs Pekajowa gave Mama a diamond ring, carpets and other things that we had left with her. She also gave us some money. The paintings, which her husband had already seen, she was afraid to give back to us though. And there would be no place to hang them. [...] She gave me a beautiful dress and presents for Mama. She truly liked us. [...] When she came to our place, she always wiped away tears and crossed herself. ${ }^{27}$

Some people with whom possessions had been left during the war were not willing to give them up afterwards. Some claimed, sometimes truthfully, that they had lost everything during the war, that the property was taken away by the occupiers, or that they were forced to sell it to support their families. "[...] They simply did not expect us to return," writes Roma Ligocka. "Most did not. Maybe they sold those things during the war because they themselves had no money..." 28 Some of those who were given items for safekeeping claimed that nothing was stored with them, or they did not remember that they had been entrusted with anything. Roma Ligocka's mother complained about this to her daughter, who would remember the conversation for years: "Imagine, my parents left almost all of our possessions with our neighbours and acquaintances. Silver, carpets, paintings and furs. Even a piano. And now people don't remember it at all." 29 Stella Müller-Madej raises questions as to the fate of pre-war Jewish property. The drama of the situation, where survivors found themselves deprived of any kind of property, resonates: "Where have the belongings of the millions who were killed gone? My father always repeated, 'The most important thing is that we're alive.' He's right, but it is not

\footnotetext{
${ }^{26}$ Kornblum-Rosenberger 1986: 97. Translated from the Hebrew by R. Vater.

${ }^{27}$ Friedman 1997: 108.

${ }^{28}$ Ligocka 2004: 220.

${ }^{29}$ Ibid.: 219.
} 
even a substitute for our pre-war life. Why can we not recover our flat? What has happened so that my parents have nothing from before the war?" 30

\section{In the maze of regulations, in the labyrinth of coteries and personal dependencies - flat allocations}

Fearing for their own safety and suffering from health problems and difficult financial situations, few returnees decided to fight in the courts for the return of their property and homes. In light of their inability to return to their own homes, they tried to find a new roof to put over their heads, but this was made difficult by the overcrowding of the cities as the result of migration, and by places being taken over by representatives of the new communist authorities, army and security services. ${ }^{31}$ The authorities did not only occupy flats, but also decided on their distribution among those residents with no ties to the state apparatus. ${ }^{32}$ Post-war legislation introduced the concept of flat allocations (przydziat mieszkania). Housing commissions (komisje mieszkaniowe) and then accommodation offices (urzędy kwaterunkowe) obtained the right to assign new tenants to the flat of the main tenant. The minimum number of people that could occupy a residence as well as the minimum usage area per tenant was also established through a top-down process.

In Polish cities, flooded by successive waves of displaced people, free flats were worth their weight in gold. If one was found, it most often was occupied without waiting for the official allocation. Henryk Grynberg recalls the fight for elegant, wellfurnished, formerly German flats in post-war Łódź:

We stayed with the Nusens, the Fryds [friends from the author's hometown], and the Meinemer brothers and their sister Belcia from Minsk Mazowiecki, who were all sharing an apartment with kitchen, bath, and four other rooms laid out in railroad style. Each of the rooms was furnished in a different color: coffee, cream, cocoa, and chocolate. There was a gleaming grand piano in the living room and the floors were a shiny parquet that squeaked slightly. Even the squire in Radoszyna [the place Grynberg hid during the war] had never lived like this. Or had furniture like this. [...] The hangings with German lettering had been placed upside down on the floor and were used for wiping your feet. There had been many apartments like this when the Nusens and the Fryds arrived in Lodz. They were almost completely untouched because they had been guarded by soldiers [...]. A note on the door would say that the apartment had been taken by corporal, noncom, or sergeant so-and-so, and everyone knew you had to find that corporal or sergeant, pay him a suitable sum, and then you could move in. ${ }^{33}$

Grynberg and his mother soon moved out of the Fryd-Nusen flat and got their own room with a kitchen. They quickly found that it was not only necessary to know how to find a flat, but also how to keep it:

\footnotetext{
${ }^{30}$ Müller-Madej 2001: 58.

${ }^{31}$ Chwalba 2004: 59.

${ }^{32}$ For more on this topic, see Jasieński 1974; Paczyńska 1994; Klich-Kluczewska 2005; Jarosz 2010.

${ }^{33}$ Grynberg 1993: 52-53.
} 
A few days after we moved in, somebody who had paid the same soldier my mother had, arrived and demanded we vacate the apartment. Fortunately, both Gaworczyks [the neighbours occupying the front part of the flat] were home. They took the man by the arms and threw him out. My mother went immediately to the Housing Department to get an official allocation. They told her they didn't issue allocations to people who had moved in illegally. Which meant they wanted a bribe, too. My mother went to see Comrade Jasinski, an older man who was the head of the Housing Department, and told him some of what we'd been through during the Occupation. She was given an official allocation, two copies. Jasinski told her to nail one up on the door, and to hide the other one well. ${ }^{34}$

In the Grynbergs' case, those who helped them keep their flat were their Polish neighbours and a sympathetic official, who not only circumvented the law but also did so without a bribe. The card with the information about the flat's allocation was soon pulled off the Grynbergs' door and the man who claimed to be occupying their flat came to their room accompanied by a policeman. The second copy of the confirmation of allocation, which Henryk Grynberg's mother had hidden on the advice of the official, discouraged him for good. The danger of losing their home had been averted.

\section{"The charms of life in a comunalka" 35 - Kraków and Lódź Jews and their neighbours}

It was safer to live with a group of friendly people, with friends or relatives, than with strangers. It was thus easier to defend one's state of ownership, and sharing living quarters with people one knew and accepted was less troublesome than doing so with strangers. Marcin Zaremba points out how the accommodation offices most often divided the large pre-war flats according to the model of "one room - one family." In this way, some got a room with a bathroom and others with a kitchen. Some had access to a staircase, others came in via the former servants' entrance. These flats were called "comunalkas" [komunałki - communal apartments] or kolkhozes. ${ }^{36}$ Salomea Kape recalls one such flat in Łódź: "[...] The new, incompetent city authorities assigned a pair of newlyweds to the room that separated our kitchen from the bedroom. This surreal, senseless division of the flat robbed us all of the sense of freedom in our own home." 37 Everyday living in these conditions required patience, self-control, tolerance and flexibility. Nevertheless, it was sometimes possible to create the atmosphere of a real home. This was the case with the residents of the tenement at 31 Piotrkowska Street, among whom was Włodzimierz Szer:

[The flat] was located in the front part of the building, on the third floor. From the hallway, one entered a large front hall. On the right were doors to two big, nice rooms, overlooking Piotrkowska Street. These were the brothers' rooms, and later the couples': Oskar and

\footnotetext{
${ }^{34}$ Ibid:: 60.

${ }^{35}$ Szer 2016: 155.

${ }^{36}$ Zaremba 2012: 487.

${ }^{37}$ Kape 2014: 170.
} 
Celinka's and Zygmunt and Maryla's. On the left, there was a small room that Felusia [the author's future wife] occupied after her arrival. [...] And further on was an entrance to the very important, large dining room that was the epicentre of all social and other kinds of life's experiences. A long passage led from the dining room to the kitchen; on the left there was a bathroom and a small room called 'the staff room' since in the past it was where the maid used to live. Hanka and her baby lived there; it was convenient, located between the bathroom and the kitchen. In the kitchen there was an entrance to a separate hallway, which led to the backyard, so the lady and the gentleman of the house who were using the main hallway wouldn't, God forbid, run into the servants and suppliers of milk, bread etc. The apartment was typical of the rich upper middle class of the end of the nineteenth and beginning of the twentieth centuries, and it was not remarkable. But for us, at that time, it was the height of luxury and chic. I am not able to name all those who passed through our dining room during the year and a half when 31 Piotrkowska Street was operating (Spring 1945-Fall 1946). Passing through meant: they ate, drank, slept - mainly on the floor - how else, how would one get so many beds and blankets - until they found either relatives or a better place under the sun. This was a warm and a welcoming home created by decent people..$^{38}$

Jews returning to Kraków and Łódź searched for friends and relatives with whom they could live, not only to avoid sharing their flats with strangers, but primarily for emotional reasons. They built a substitute family and could feel more comfortable and safer amongst them. Because they were united by their pre-war past and community of war experiences, they felt obligated to mutually support one another. In Włodzimierz Szer's home lived friendly lodgers, some of whom were related, joined by shared history and shared experiences, their fates many times interwoven. Thanks to this, their everyday lives were full of warm relations. The mother of Yoram, Natan and Klara Gross took in her sister and her children who had been repatriated from the Soviet Union: "Our dear Mama always had a big heart. So, when her sister Mala with her four children returned from Russia - and as a widow - naturally, she took them in. Two days before my delivery date, the lodger in the neighbouring room died and, before the accommodation office could allocate it to someone, Mama transported my aunt and her children there. ${ }^{39}$ Creating a community of survivors, a camp family, ${ }^{40}$ taking in friends, relatives, and sometimes also complete strangers seeking shelter and met by chance, was a rather common phenomenon. Stella Müller-Madej writes: "[Father] often left. He nearly always brought back some lonely man, usually in concentration camp rags $[\ldots]^{41}$ Through the house passed many people, those who had returned from the camps, searching and waiting for their families, and also old friends of my parents. It's cramped; seven people live in two rooms." ${ }^{2}$ The flats became increasingly cramped and crowded, but for those who had shared difficult wartime fates there was always room. Halina Nelken writes: "Every apartment was bursting at the seams, and it was normal to take strangers,

${ }^{38}$ Szer 2016: 136-137.

${ }^{39}$ Gross 2006: 33-34.

${ }^{40}$ For more on creating a community of survivors, see Dvorjetski 1963: 213-214; Koźmińska-Frejlak 1999: 133.

${ }^{41}$ Müller-Madej 2001: 6.

${ }^{42}$ Ibid.: 12. 
or people who had shared the same misery, in under one's roof." ${ }^{43}$ Rachel Grynfeld recalls that after returning to Łódź she went to the house at 26 Kościuszki Street, which her parents had purchased with a friendly Pole, Mr Wesołowski. Mr Wesołowski welcomed her with open arms - a rare occurrence - and gave her, as the sole inheritor of her family, a three-room flat in the tenement. Unfortunately, it was quickly requisitioned by a Russian officer, so Mr Wesołowski gave her another and equipped it with furnishings and bedding. Rachel Grynfeld writes that she immediately took in friends who, like her, had survived the camps and who after the war could not count on the support that she received. These young, orphaned women created a substitute family, shared their money and jointly ran a household. ${ }^{44}$

More often than not, Jewish people returning to Kraków and Łódź shared flats with strangers rather than friends and family. In the subdivided flats people of different backgrounds lived side-by-side, with different levels of education, different pre-war and wartime experiences, and diverse possessions. In observing the shared apartments so widely described in Jewish personal accounts, we can see a cross-section of Polish society of the 1940s. The elegant, spacious apartments belonging before the war to the most affluent social strata became quarters for workers, migrants to cities from the countryside, repatriates, former prisoners of concentration camps and, not infrequently, people from the margins of society. The loss of the right to freely dispose of one's flat - the last symbols of social prestige and position - was a visible sign of the degradation of their owners and an effective tool of the class struggle used by the state. Alona Frankel, whose father was already a communist before the war, writes that thanks to the favouritism her family received a room in an elegant, luxurious flat whose owner - a pre-war landowner - considered them to be the worst of the lodgers because they were Jewish:

It finally paid off to be a communist. It [...] was a room in a shared flat. A peculiar, post-war community. A six-room apartment with a shared kitchen and bathroom. In the corner house at 1 Sobieskiego Street. The entrance was once elegant and magnificent. [...] The flat was huge. Expensive parquet floors, side glass doors and high French windows. In the past, before the war, was occupied alone by an oldish landowner, Mrs Jarosława Morawska. It was her city residence. She also had a manor house not far from Kraków. The estate, including the manor and all of its furnishings, was nationalised after the war, while in Mrs Morawska's lovely Kraków apartment a variety of strange occupants were quartered in accordance with the decree of the new authorities. We arrived last - and we were Jews. The worst of all. Mrs Morawska, in the name of fairness and equality, must content herself with one room, and not even the largest or most elegant. ${ }^{45}$

Alona Frankel mentions that the elegant tenement on Sobieskiego Street had a janitor, Józefowa, who was engaged in various activities in order to feed her ever-expanding family, as her husband was an alcoholic:

Her husband hung around all day in an alcoholic haze on a stool on the staircase [...]. From his corner, belched the odour of alcoholism, sadness and embitterment. He never worked.

\footnotetext{
${ }^{43}$ Nelken 1999: 268.

${ }^{44}$ Grynfeld 2005: 57-58.

${ }^{45}$ Frankel 2007: 84-85.
} 
[...] Józefowa, who the communist regime had not yet managed to embrace with its justice, heroically and with great determination attempted to feed her beloved children and husband, the sad alcoholic who drank denatured alcohol and sucked the blood out of her. In addition to working hard cleaning the staircases and the courtyard, she took in rolled up carpets from wealthier families and beat them with a wicker carpet beater. ${ }^{46}$

Poor people, often on the margins of society, populate the social space of most of the analysed literary personal accounts. They are present e.g. in the neighbourhood community described by Eva Hoffman. She writes that people of various backgrounds lived in the tenement at 79 Kazimierza Wielkiego Street, making it an arena for unusual events; it represented the world in microcosm, with all of its absurdities and misfortunes, but also its small joys:

The three-story building is full of talk, visits, and melodrama. The dragon caretaker is married to a thin, forlorn man, at whom she shouts perpetually and whom one day she stabs with a knife. After that, he slumps even more sadly than before, avoids everyone, and takes to breeding chickens in the enormous attic under the roof. Their squawks and flying feathers turn the interior into a place of Bruno Schulz surrealism, and I'm drawn there as if it were inhabited by magic. The other downstairs apartment is occupied by a shoemaker, who, in more classic style, gets drunk and beats his wife. [...] Then are the real neighbours - people between whose apartments there's constant movement of kids, sugar, eggs, and teatime visits. ${ }^{47}$

The shared apartments became a space for a constant test of strength between neighbours. The winner was the person with the largest family, better connections and the most cunning. Holocaust survivors, often living alone or in small families and deprived of communal support, were condemned in advance to lose these competitions. They often did not have the strength to fight for the right to use the shared spaces, such as the kitchens or bathrooms. Janina Katz writes:

We moved to 22 Zielona Street, to the house where my parents lived before I was born. But we did not live in the same two-room flat [...]. We lived together with the Nowak family and Mrs Nowak's mother. [...] Lola [the mother] and I got the smallest room, but it was rather large because we did not have any furniture. ${ }^{48}$ It was Mama who got this flat thanks to her old acquaintance, but from the very beginning the Nowak family, which was larger, that decided what we were allowed or not allowed to do. First off, they forbade us access to the kitchen. But we did not really need the kitchen. Lola immediately purchased an electric stove for making coffee and frying eggs. ${ }^{49}$

The initial organisational difficulties were eventually overcome, and Mrs Nowakowa even became Janina Katz's godmother when she decided to convert to Catholicism. Mrs Nowakowa even gifted her with a gold chain with a medallion depicting the Madonna. Nothing could have foretold the disaster that ensued. As Janina Katz

\footnotetext{
${ }^{46}$ Ibid.: 213-214.

${ }^{47}$ Hoffman 1990: 12.

${ }^{48}$ Katz 2006: 85.

${ }^{49}$ Ibid:: 86.
} 
writes, one day the lady became "sick with anger" ${ }^{50}$ and turned against her goddaughter and Lola. The author states that the torment at home caused her to often seek shelter at her friend's house: "Mornings and evenings were the worst. In the morning, she relieved herself in front of our door; in the evenings she took long baths. The bathroom adjoined our room and Mrs Nowakowa drilled a hole in the wall. At night, we were woken by her throwing pieces of the wall on the floor." ${ }^{1}$ Katz recalls that she and her mother had nowhere to escape for a long time because they knew no one who could help them obtain another flat. The situation worsened: "Mrs Nowakowa hit her [the author's mother] in the stomach, screaming: 'You damned Jewess!' My godmother! They were supposed to meet in court." 52 The author writes that they finally managed to free themselves from this embarrassing and awful neighbour. They found a new flat: "Once again, we lived in one room, but we were friendly with the family who occupied the second room of the flat, although their life was much more colourful than we would have liked; blood and, more often, vodka, flowed frequently." ${ }^{53}$

In personal accounts written by Jews, we can not only find images of conflict between Polish and Jewish neighbours, but also between Jewish neighbours. When an opportunity to take over an entire apartment appeared, close ties sometimes fell apart. Włodzimierz Szer, whose recollections of the shared apartment at 31 Piotrkowska Street are the most positive, did not have many good memories of his next residence. With his family growing larger, he moved to a room on Bandurskiego Street vacated by his cousins. The change of address took place without the participation of the accommodation office. In his memoirs, which are addressed to his children, he describes the conflict with the new neighbour - his cousin Sabina:

[...] Sabina treated us like intruders. She was furious, hoping to have the entire apartment to herself. She made our lives a misery, especially Felusia's, who spent more time at home than I did. One day your mom, while holding Karusia [the daughter] was cooking something in the common kitchen, which was, because of its function, the main battlefield. Sabina, holding the dog, said to her boyfriend: 'There isn't a child in this world whose eyes are more beautiful than my Fly's [dog's].' Your mom, who wasn't very resilient, fled the kitchen and began to avoid the cousin like a plague. One day, Sabina told us that she would sue us since we had occupied the apartment illegally and that I would go to jail, but that she, in respect for my parents, whom she had known before the war, would be the first one to bring me food parcels to prison. The woman wasn't altogether sane. According to Felusia [the author's wife], I responded that I would be the first to bring flowers to her grave. Those were the charms of life in a comunalka. ${ }^{54}$

\footnotetext{
${ }^{50}$ Ibid: : 130.

${ }^{51}$ Ibid:: 131.

${ }^{52}$ Ibid.: 154.

${ }^{53}$ Ibid.: 161.

${ }^{54}$ Szer 2016: 154-155.
} 


\section{Summary}

Kraków and Łódź Jews who survived the Holocaust returned to their hometowns where seemingly nothing had changed - the trams still traversed the city, riding on the same tracks; the familiar streets led to the pre-war squares and parks; even their homes still stood on the same streets. Only the flats of the survivors were not empty; they were not waiting for their rightful owners. It could be attempted to recover a flat that has been occupied by others through the courts, but a survivor did not often have the strength or the resources to do so. As a result, in accordance with the post-war legislation, the survivors found their ways to apartments divided by the accommodation offices. Their neighbours were different people - from pre-war aristocrats to people on the margins of society. Images of these difficult, tension-filled neighbourhoods can be found in Jewish personal accounts. Certainly, it was hard for everyone involved - it is not easy to share space with strangers. It seems, however, that for Holocaust survivors, deprived of communal support and traumatised by war, it was the most difficult. The indifferent, often hostile, world around them took on the figure of their neighbours, forced its way into their homes and stripped them of their sense of safety, stability, and hope for a return to normal life. Many survivors could not bear the burden of such a difficult day-to-day existence - they left Poland, looking for safe haven elsewhere.

\section{BIBLIOGRAPHY}

\section{Literary personal accounts}

Bau, J. (1995), Spotkanie po..., Kontury: 39-42.

Bronner, I. (1991), Cykady nad Wisła i Jordanem, Kraków.

Frankel, A. (2007), Dziewczynka, transl. L. Kwiatkowski, Warszawa.

Friedman, E. (1997), Daleka droga do domu, Kraków.

Gross, N. (2006), Przygody Grymka w Ziemi Świętej, Kraków.

Gross, Y. (2011), My Animated Life, transl. M. Weyland, Blackheath.

Grynberg, H. (1993), The Victory, transl. R. Lourie, Evanston.

Grynfeld, R., Grynfeld, E. (2005), Gwizd życia, transl. Sz. Raczyńska, Łódź.

Hoffman, E. (1990), Lost in Translation, New York.

Kape, S. (2014), Kocham Twa urodę zła, najdroższe miasto na świecie. Wspomnienie z getta łódzkiego, Warszawa.

Katz, J. (2006), Moje życie barbarzyńcy, transl. B. Sochańska, Warszawa.

Kaufman, L. (2009), Luna's Life: A Journey of Forgiveness and Triumph, Margate.

Kornblum-Rosenberger, R. (1986), Neder. Zihronot 1939-1945, Tel Aviv.

Lasman, N. (1997), Wspomnienia z Polski: 1 sierpnia 1944 do 30 kwietnia 1957, Warszawa.

Ligocka, R. (2003), The Girl in the Red Coat: A Memoir, with I. von Finckenstein, transl. M. Bettauer Dembo, New York.

Ligocka, R. (2004), Tylko ja sama, transl. S. Lisiecka, Kraków.

Müller-Madej, S. (2001), Dziewczynka z listy Schindlera. Lata powojenne, Kraków.

Nelken, H. (1999), And Yet, I Am Here!, transl. H. Nelken, A. Nitecki, Amherst.

Redlich, Sh. (2010), Life in Transit: Jews in Postwar Lodz, 1945-1950, Boston.

Szer, W. (2016), To Our Children: Memoirs of Displacement. A Jewish Journey of Hope and Survival in Twentieth-Century Poland and Beyond, transl. B. Karst, Boston.

Vogler, H. (1981), Autoportret z pamięci. Część trzecia. Dojrzałość, Kraków. 


\section{Secondary literature}

Bieberstein, A. (1986), Zagłada Żydów w Krakowie, Kraków and Wrocław.

Cichopek-Gajraj, A. (2014), Beyond Violence: Jewish Survivors in Poland and Slovakia, 1944-1948, Cambridge.

Chwalba, A. (2002), Dzieje Krakowa 5: Kraków latach 1939-1945, Kraków.

Chwalba, A. (2004), Dzieje Krakowa 6: Kraków w latach 1945-1989, Kraków.

Czocher, A. (2011), Bohaterki codzienności. Kobiety w Krakowie w okresie okupacji 1939-1945, in: A. Czocher et al., Wojna to męska rzecz? Losy kobiet w okupowanym Krakowie w dwunastu odsłonach, Kraków: 14-27.

Dvorjetski, M. (1963), Adjustment of Detainees to Camp and Ghetto Life and Their Subsequent Readjustment to Normal Society, Yad Vashem Studies 5: 193-219.

Eberhardt, P. (2000), Przemieszczenia ludności na terytorium Polski spowodowane II wojna światowa, Warszawa.

Grabowski, J., Libionka, D. (eds.) (2014), Klucze i kasa. O mieniu żydowskim w Polsce pod okupacja niemiecka $i$ we wczesnych latach powojennych 1939-1950, Warszawa.

Gross, J.T. (2006), Fear: Anti-Semitism in Poland after Auschwitz. An Essay in Historical Interpretation, New York.

Gross, J.T. (2008), Strach. Antysemityzm w Polsce tuż po wojnie. Historia moralnej zapaści, Kraków. Grzebałkowska, M. (2015), 1945. Wojna i pokój, Warszawa.

Jarosz, D. (2010), Mieszkanie się należy... Studium z peerelowskiech praktyk społecznych, Warszawa.

Jasieński, J. (1974), Problemy mieszkalnictwa w rozwoju Krakowa, Kraków.

Kersten, K. (2005), Ruchliwość w Polsce po II wojnie światowej jako element przeobrażeń społecznych i kształtowania postaw, in: K. Kersten, Pisma rozproszone, comp. T. Szarota, D. Libionka, Toruń: 175-197.

Klich-Kluczewska, B. (2005), Przez dziurkę od klucza. Życie prywatne w Krakowie (1945-1989), Warszawa.

Koźmińska-Frejlak, E. (1999), Polska jako ojczyzna Żydów - żydowskie strategie zadomowienia się w powojennej Polsce (1944-1949). Zarys problematyki, Kultura i Spoleczeństwo 1: 119-141.

Krawczyk, M. (2011), Status prawny własności żydowskiej i jego wpływ na stosunki polsko-żydowskie, in: F. Tych, M. Adamczyk-Garbowska (eds.), Następstwa zagłady Żydów. Polska 1944-2010, Lublin: 687-713.

Krzyżanowski, Ł. (2016), Dom, którego nie było. Powroty ocalałych do powojennego miasta, Wołowiec.

Lech, A., Radziszewska, K., Rykała, A. (eds.) (2010), Spoleczność zydowska i niemiecka w Łodzi po 1945 roku, Łódź.

Leociak, J. (2005), Literatura dokumentu osobistego jako źródło do badań nad zagładą Żydów. Rekonesans metodologiczny, Zagłada Żydów. Studia i Materiaty 1: 13-31.

Löw, A., Roth, M. (2011), Juden in Krakau unter deutscher Besatzung 1939-1945, Göttingen.

Paczyńska, I. (1994), Gospodarka mieszkaniowa a polityka państwa w warunkach przekształceń ustrojowych w Polsce w latach 1945-1950 na przykładzie Krakowa, Warszawa.

Radziszewska, K. (2010), Społeczność niemiecka w Łodzi w latach 1945-1950, in: A. Lech, K. Radziszewska, A. Rykała (eds.), Społeczność żydowska i niemiecka w Łodzi po 1945 roku, Łódź: 209-229.

Rzepkowski, A. (2008), Skład narodowościowy, wyznaniowy i językowy ludności Łodzi w Drugiej Rzeczypospolitej, Przeglad Nauk Historycznych VII (1): 87-104.

Sienkiewicz, W., Hryciuk, G. (eds.) (2008), Wysiedlenia, wypędzenia i ucieczki 1939-1945. Atlas ziem Polski. Polacy, Żydzi, Niemcy, Ukraińcy, Warszawa.

Szymańska, M. (comp.) (2015), Powroty. Warszawa 1945-1946, Warszawa.

Zaremba, M. (2012), Wielka trwoga. Polska 1944-1947. Ludowa reakcja na kryzys, Kraków.

Zimmerer, K. (2004), Zamordowany świat. Losy Żydów w Krakowie 1939-1945, Kraków.

Zimmerer, K. (2017), Kronika zamorodowanego świata. Żydzi w Krakowie w czasie okupacji niemieckiej, Kraków. 